\title{
PRIORITIZATION OF NEW PRODUCT DEVELOPMENT ACTIVITIES FOR ELECTRONICS MANUF ACTURING
}

\author{
Eduardo Gomes Salgado* \\ Federal University of Alfenas \\ Alfenas, MG, Brazil \\ Sao Paulo State University \\ Guaratingueta, SP, Brazil \\ E-mail: eduardosalgado@unifal-mg.edu.br \\ Valerio A. P. Salomon \\ Sao Paulo State University \\ Guaratingueta, SP, Brazil \\ E-mail: salomon@feg.unesp.br \\ Carlos Henrique Pereira Mello \\ Federal University of Itajuba \\ Itajuba, MG, Brazil \\ E-mail: carlos.mello@unifei.edu.br
}

\begin{abstract}
The New Products Development (NPD) is a managerial process, accomplished of many activities. The purpose of this paper is to present the application of the Analytic Hierarchy Process (AHP) to prioritize activities of NPD in manufacturing companies of electronics products. An industrial cluster located in Brazilian Southeast was studied. This way, ten of 42 activities from an NPD model were suggested to be excluded for the electronics companies. These activities have less than $0.5 \%$ overall priority. The results from AHP application were welcomed by companies NPD experts.
\end{abstract}

Keywords: AHP, electronics manufacturing, new product development.

\section{Introduction}

The importance of New Products Development (NPD) has been, significantly, increased. The search for the innovation and new products release, with market acceptance, concerns to companies worldwide (Brentani, et al., 2010). In industrial branches, as aerospace, automotive, and electronics, NPD is fundamental for companies' survival (Tyagi, and Sawhney, 2010).

The NPD can be considered as a managerial process, accomplished of many activities. These activities will demand time and resources for their execution. The purpose of this paper is to present the application of the Analytic Hierarchy Process (AHP) to prioritize activities of NPD in manufacturing companies of electronics products. Concepts of Group Decision Making (Saaty and Peniwati, 2007) will be considered when taking the know ledge from real companies.

The main objective of the AHP application is to help managers to prioritize NPD activities. Because, in practice, it can be very difficult to perform all activities with the same attention. Some NPD activities are

\footnotetext{
* Corresponding author
} 
more susceptible to suffer changes during NPD. This way, NPD management can be more effective, better controlling the higher priorities activities.

\section{The Process of New Product Development}

The process of NPD can be understood as a sequence of activities performed to develop new products, from an initial idea to its production discontinuation. In this process, the customers' desires must be identified, or else, translated into product specifications to generate business and technical solutions (Clark, and Fujimoto, 1991; Peters, et al., 1999; Rosenthal, 1992; V incent, 1989; Wheelwright, and Clark, 1992).

Although a variety of companies recognizes how NPD is important to their business, the failure rate of new products is high. There are diverse reasons for such high rate, however, a common reason is the absence of systemic use of models, tools, and techniques NPD (Gonzalez and Palacios, 2002; Rundquist and Chibba, 2004). That is, in the same company, a new product can be developed with more effort spent to market researches, and another product is developed focusing on company's manufacturing constra ints. This way, the errors incurred in the first NPD will not be avoided for future products. Prioritizing NPD activities related with market research, or prioritizing the activities related to manufacturing constraints for instance, maybe a way to avoid errors occurred in previous NPD. This way, the prioritization of NPD activities can reduce the new products failure rate.

According to Salgado et al. (2010), from the end of the 1990's, several models of NPD process has been proposed to specific industrial branches: automotive industry (Rozenfeld, et al., 2006), brewery industry (Nwabueze and Law, 2001), electronics industry (Ledwith, 2000), food industry (Rudolph, 1995), and furniture industry (Bumgardner, et al., 2001), to name a few. Even with every model has been proposed to a specific field of business, the models can be considered as very similar. Most of the models are divided in "activities", "stages" or "phases". Besides this variation in the nomenclature, the models also vary in the number of macro-activities and in the number of activities inside every macro-activity.

In Section 3, the AHP will be applied to the prioritization of activities of an NPD model. This model was proposed and previously tested in automotive companies. But, in this paper, the suitability of the model to electronics industry will be also proved.

\section{Analytic Hierarchy Process Application}

The prioritization of the activities of NPD can be considered as a Multi-Criteria Decision. This is because that NPD models are composed by so many activities, that, for better understanding, they are grouped as in macro-activities, phases, or stages. This grouping facilitates the AHP application, since "fundamental aspect of the AHP is making paired comparisons of homogeneous activities" (Saaty, 2010). The AHP can be applied to prioritize the groups, and then, to prioritize alternatives ins ide the groups. A limitation of AHP application is that the alternatives must be considered as independent. That is the application of another Multi-Criteria method, the Analytic Network Process (ANP) could be take in consideration the inter-relations among the alternatives. As this paper presents preliminary study on this them, the AHP application was adopted as limitation.

As commented in Section 2, Rozenfeld, et al. (2006) proposed an NPD model to automotive industry. But, they also tested the suitability of their model to other industrial branch: the white-goods industry, that is, the electrical household appliances industry. The 42 activities of this NPD model are distributed in three sequential phases: Pre-Development (P1), Development (P2), and Post-Development (P3). The 
activities are also grouped in macro-phases, as Strategic Planning, which is composed by four different activities. Figure 1 presents the hierarchical framework to prioritization of this model's activities.

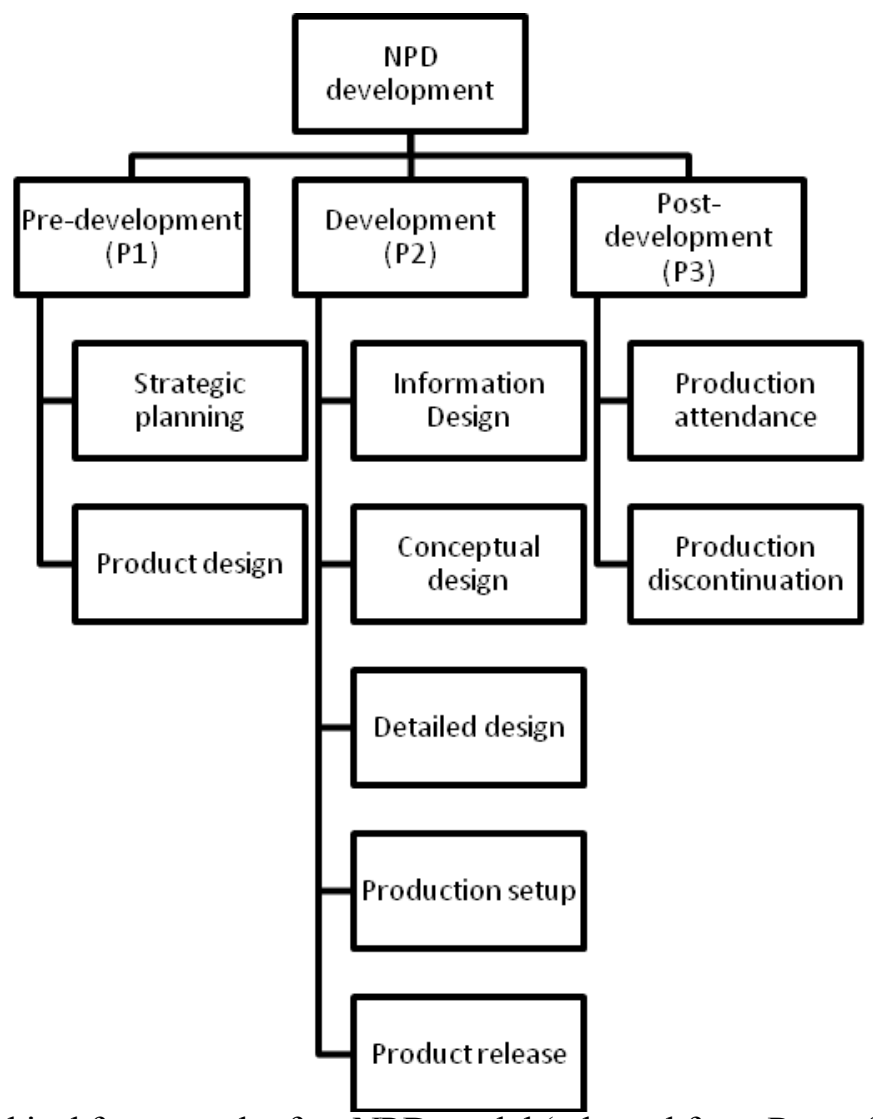

Figure 1. Hierarchical framework of an NPD model (adapted from Rozenfeld, et al., 2006).

The suitability of the NPD model to electronics industry will be proved with the study of an industrial cluster located in Brazilian Southeast. In Santa Rita do Sapucai, a typical Brazilian small town, more than 120 small companies produce components, parts, and whole products, providing for $70 \%$ of Brazilian radio-broadcast market. Research and Development (R\&D) experts from three leading companies, in terms of product innovation, were contacted and agreed to take part of this research. All these experts are graduated in Electrical Engineering and have more than 10 years of experience in product development or project management. Expert 1 was the Development Manager for Company A, a safety alarms manufacturer. Expert 2 was the Industrial Director for Company B, a manufacturer and assembler of radio transmitters. Expert 3 was R\&D Manager for Company C, a manufacturer of business telephone systems (mainly PBX systems).

An academic version of web-based AHP software was used to make the data collection and processing. So, one of the co-authors of these work create an online file, in this platform. After he input the hierarchy (Figure 1) in the software, the experts were defined as evaluators. Then, each expert received a message by e-mail with short instructions on how to access and input the ir opinions in the website. The experts were also personally contacted and informed on the research's objectives.

Table 1 presents the comparisons among NPD model's phases, provided by Experts 1 . Even with the software uses the Fundamental Scale, a rational $3 / 2$ for a comparison between P1 and P2 was also permitted. The comparison matrix presented in Table 1 is totally consistent, as all other comparisons matrices provided by the experts. This is an indication that experts understood what they are judging. 
Table 1. Priorities of NPD phases according to Expert 1.

\begin{tabular}{|l|c|c|c|c|}
\hline NPD Phase & P1 & P2 & P3 & Priority \\
\hline Pre-Development (P1) & 1 & $3 / 2$ & 1 & $37.5 \%$ \\
\hline Development (P2) & $2 / 3$ & 1 & $2 / 3$ & $25 \%$ \\
\hline Post-Development (P3) & 1 & $3 / 2$ & 1 & $37.5 \%$ \\
\hline
\end{tabular}

As the experts have been working for different companies, the Aggregation of Individual Judgments (Saaty and Peniwati, 2007) was applied to aggregate their comparisons. The experts were considered as equally important. That is, the comparis ons had the same weight when aggregated. The whole data collection spends less than one month. Table 2 presents the aggregated priorities of NPD phases. Despites some divergence among the priorities vector form each expert, Pre-development were considered as the highest priority phase by all the experts. This is also according to recent researches those pointed the proper study to product commercialization as a success factor to NPD (Liginlal, et al., 2006).

Table 2. Aggregated priorities of NPD phases.

\begin{tabular}{|l|c|c|c|c|}
\hline NPD Phase & Expert 1 & Expert 2 & Expert 3 & Overall \\
\hline Pre-Development & $37.5 \%$ & $97 \%$ & $53 \%$ & $78 \%$ \\
\hline Development & $25 \%$ & $2 \%$ & $31 \%$ & $9 \%$ \\
\hline Post-Development & $37.5 \%$ & $1 \%$ & $16 \%$ & $13 \%$ \\
\hline
\end{tabular}

As Companies A to C are small companies, all of their NPD experts considered the NPD model proposed by Rozenfel, et al. (2006) too complex. That is some activities were considered as not necessary to their reality. This way it was suggested that activities with less than $0.5 \%$ of overall priority were excluded from this NPD processes. Ten from the 42 activities of NPD were suggested to be excluded. However, the permanent exclusion of these activities will $b$ subject of Action Researches to be performed in the year of 2011.

\section{Conclusions}

This paper presented the AHP application to the prioritization of NPD activities. An NPD model proposed to automotive parts were analyzed and it was considered suitable to electronics manufacturers companies. However, the original model was considered too complex to be fully adopted. This way, ten of its 42 activities were suggested to be excluded for the electronics companies studied. These activities have less than $0.5 \%$ overall priority.

The results from AHP application were welcomed by companies NPD experts. But, the definitive results adoption in each company is now carefully studied with Actions Researches. One limitation of the prioritization was the AHP application. The activities were considered as independent. Perhaps, interactions occur among several activities. This way, the replication of the presented study with an ANP application may be subject for future research.

\section{ACKNOWLEDGMENT}

The academic version of the web based AHP software was acquired with financial support from Brazilian Council of Scientific and Technological Development, under the grant no. CNPQ 483583/2009-0. 


\section{REFERENCES}

Brentani, U., Kleinschmidt, E.J., \& Salomo, S. (2010). Success in global new product development: impact of strategy and the behavioral environment of the firm. Journal of Product Innovation Management, 27, 143-160.

Bumgardner, M.S., Bush, R.J., \& West, C.D. (2001). Product development in large furniture companies: a descriptive model with implications for character-marked products. Wood and Fiber Science, 33, 302313.

Clark, K.B., \& Fujimoto, T. (1991). Product development performance: strategy, organization and management in the word auto industry. Boston: Harvard Business School Press.

Ledwith, A. (2000). Management of new product development in small electronics firms. Journal of European Industrial Training, 4, 137-148.

Liginlal, D., Ram, S., \& Duckstein, L. ( 2006). Fuzzy measure theoretical approach to screening product innovations. IEEE Transaction on Systems Man and Cybernetics, 36, 577-591.

Nwabueze, U., \& Law, Z.C. (2001). The journey for survival: the case of new product development in the brewery industry. Journal of Product \& Brand Management, 10, 382-397.

Peters, A.J., Rooney, E.M., Rogerson, J.H., McQuater, R.E., Spring, M., \& Dale, B.G. (1999). New product design and development: a generic model. The TQM Magazine, 11, 172-179.

Rosenthal, S.R. (1992). Effective product design and development - how to cut lead time and increase customer satisfaction. New York: Irwin Professional Publishing.

Rozenfeld, H., Forcellini, F.A., Amaral, D.C., Toledo, J.C., Silva, S.L., Alliprandini, D.H., \& Scalice, R.K. (2006) Product development management. Sao Paulo: Saraiva, 2006 [In Portuguese].

Rudolph, M.J. (1995). The food product development process. British Food Journal, 97, 3-11.

Saaty, T.L., \& Peniwati, K. (2007). Group Decision Making. Pittsburgh: RWS Publications.

Saaty, T.L. (2010). Principia Mathematica Decernendi. Pittsburgh: RWS Publications.

Salgado, E.G., Salomon, V.A.P., Mello, C.H.P., Fass, F.D.M., Xavier, A.F. (2010). Product development reference models: classification, analys is and suggestions for future research. Producao Online, 10, 886911 [In Portuguese].

Tyagi, R.K., \& Sawhney, M.S. (2010). High-performance product management: the impact of structure, process, competencies, and role definition. Journal of Product Innovation Management, 27, 83-96.

Wheelwright, S.C., \& Clark, K.B. (1992). Revolutionizing product development: quantum leaps in speed, efficiency, and quality. New York: Free Press. 